\title{
Freund's Complete Adjuvant Induces Arthritis in Mice Lacking a Functional Interferon- $\gamma$ Receptor by Triggering Tumor Necrosis Factor $\alpha$-Driven Osteoclastogenesis
}

\author{
Lies Geboes, ${ }^{1}$ Bert De Klerck, ${ }^{1}$ Maarten Van Balen, ${ }_{1}^{1}$ Hilde Kelchtermans, ${ }_{1}^{1}$ Tania Mitera, ${ }^{1}$ \\ Louis Boon, ${ }^{2}$ Chris De Wolf-Peeters, ${ }^{1}$ and Patrick Matthys ${ }^{1}$
}

Objective. To investigate the hypothesis that Freund's complete adjuvant (CFA) plays an essential role in the induction of collagen-induced arthritis in mice, by testing whether CFA by itself is able to induce arthritis in interferon- $\gamma$ receptor-knockout (IFN $\gamma \mathrm{R}$ KO) mice.

Methods. IFN $\gamma \mathrm{R}$-KO and wild-type mice were sensitized with a single intradermal injection of CFA containing heat-killed Mycobacterium butyricum. Flow cytometric analysis and in vitro osteoclastogenesis assays were performed on blood, spleen, and bone marrow cells. Tumor necrosis factor (TNF) levels were measured in the serum, and levels of RANKL, osteoprotegerin (OPG), and TNF $\alpha$ in the synovium were determined by quantitative reverse transcriptase-polymerase chain reaction. Effects of treatment with the TNF $\alpha$ antagonist etanercept were assessed.

Results. Symptoms of arthritis appeared in IFN $\gamma \mathrm{R}$-KO mice but not in wild-type mice, and reached an incidence of $55 \%$. The onset coincided with an expansion of CD11b+ splenocytes that spontaneously produced TNF $\alpha$ and with increased osteoclastogenesis in spleen and blood cells. Expansion of CD11b+ splenocytes and osteoclast precursor cells was more pronounced in arthritic than in nonarthritic mice. There was a >100-fold increase in the RANKL:OPG ratio in

Supported by the Fund for Scientific Research-Flanders, the Regional Government of Flanders' GOA Program, and the Belgian Federal Government's Interuniversity Attraction Pole Program (grant IAP5/12).

Lies Geboes, Bert De Klerck, PhD, Maarten Van Balen, Hilde Kelchtermans, Tania Mitera, Chris De Wolf-Peeters, PhD, Patrick Matthys, PhD: Katholieke Universiteit Leuven, Leuven, Belgium; ${ }^{2}$ Louis Boon: Bioceros BV, Utrecht, The Netherlands.

Address correspondence and reprint requests to Lies Geboes, Immunobiology Laboratory, Rega Institute, Minderbroedersstraat 10, B-3000 Leuven, Belgium. E-mail: lies.geboes@rega.kuleuven.be.

Submitted for publication November 27, 2006; accepted in revised form April 26, 2007. the synovia of CFA-sensitized mice compared with those of naive animals. Treatment with etanercept prevented the development of arthritis and mitigated the increased expansion of myeloid cells as well as the increase in osteoclast precursor numbers in the spleen and blood.

Conclusion. These results indicate that sensitization of mice with CFA creates a condition in which dysregulation of a single cytokine leads to arthritis by triggering $\mathrm{TNF} \alpha$-driven osteoclastogenesis.

Several approaches have been developed to induce arthritis in animals by immunization with a jointspecific component emulsified in an adjuvant. Collageninduced arthritis (CIA) is one such model, and is probably the most extensively studied animal model of human rheumatoid arthritis. CIA can be induced in genetically susceptible DBA/ 1 mice by immunization with heterologous type II collagen (CII) emulsified in Freund's complete adjuvant (CFA), containing heatkilled mycobacteria (1-3). CFA is considered to increase the humoral anti-CII antibody response and to promote Th1-type cellular immunity to CII $(4,5)$. However, it is intriguing that, in rats, arthritis can easily be induced by a single injection of CFA, without a joint-specific antigen (for review, see ref. 6). Attempts at induction of this so-called "adjuvant arthritis" in other species have met with little success in that only a few animals developed disease, or onset of the disease was very late (7-9). Successful induction of adjuvant arthritis in mice upon treatment with anti-interleukin-4 antibodies has been reported (10).

In this study we tested the hypothesis that adjuvant arthritis can be induced in interferon- $\gamma$ receptorknockout (IFN $\gamma \mathrm{R}-\mathrm{KO}$ ) mice. The hypothesis derived from previously reported findings by our research group and by others that IFN $\gamma$ R-KO DBA/1 mice develop an 
accelerated and more severe form of autoimmune CIA (11-13). Moreover, knockout of the IFN $\gamma$ gene makes genetically resistant strains of mice susceptible to CIA $(14,15)$, indicating an important role of non-major histocompatibility complex (MHC) genes in the development of CIA. The increased susceptibility of IFN $\gamma \mathrm{R}-\mathrm{KO}$ mice to CIA is ascribed to the presence of heat-killed mycobacteria in CFA that is used for the induction of CIA. When mycobacteria are omitted from the arthritis induction protocol by using Freund's incomplete adjuvant instead of CFA, IFN $\gamma \mathrm{R}-\mathrm{KO}$ mice are protected against disease instead of being more susceptible (16). Also, the resistance of C57BL/6 mice to CIA can be abrogated by increasing the amount of killed mycobacteria in CFA during the immunization procedure (17).

Further work in our laboratory revealed that the severe form of CIA, when CFA is used for induction, is associated with increased expansion of CD11b + myeloid cells in the spleen, and a portion of these expanded $\mathrm{CD} 11 \mathrm{~b}+$ splenocytes are osteoclast precursor cells (18). Osteoclasts are multinucleated cells formed by fusion of mononuclear precursors that are of monocyte/ macrophage lineage $(19,20)$. Mature osteoclasts can be generated in vitro either from bone marrow myeloid progenitors or from blood monocytes and in mice from spleen cells, upon stimulation with macrophage colonystimulating factor (M-CSF) and RANKL $(18,20,21)$.

The importance of osteoclasts in the induction of erosive arthritis has recently been demonstrated in studies of spontaneously developing arthritis in mice expressing a human tumor necrosis factor $\alpha(\mathrm{TNF} \alpha)$ transgene (22-25). The joint destruction in these transgenic mice could be counteracted either by targeting osteoclasts (22) or by crossing the mice with c-Fos-deficient animals lacking osteoclasts (23). Systemic TNF $\alpha$ was found to mediate an increase in peripheral CD11b + osteoclast precursors (24) by up-regulating the expression of c-Fms, the receptor for M-CSF, an essential factor in the survival of osteoclast precursor cells (25). These results demonstrate that in the absence of a joint-specific antigen, systemic $\mathrm{TNF} \alpha$ production induces arthritis mainly by stimulating osteoclastogenesis.

We report herein that in the absence of CII, a single injection of CFA leads to full-blown arthritis in IFN $\gamma \mathrm{R}-\mathrm{KO}$ mice. The development of arthritis coincides with increased systemic production of $\mathrm{TNF} \alpha$, expansion of osteoclast formation in the periphery, and an increase in the RANKL:osteoprotegerin (OPG) ratio in the joint. Thus, under appropriate conditions, adjuvant arthritis can be induced in mice by dysregulation of a single cytokine, thereby triggering osteoclastogenesis.

\section{MATERIALS AND METHODS}

Mice. The generation and basic characteristics of the mutant mouse strain (129SvEv) with a disruption in the gene coding for the $\alpha$-chain of IFN $\gamma \mathrm{R}$ have been described (26). These IFN $\gamma \mathrm{R}-\mathrm{KO}$ mice were backcrossed with wild-type $\mathrm{DBA} / 1$ mice for 10 generations to obtain an IFN $\gamma \mathrm{R}-\mathrm{KO}$ $\mathrm{DBA} / 1$ mouse strain. The homozygous IFN $\gamma \mathrm{R}-\mathrm{KO}$ mice were identified by polymerase chain reaction (PCR) as described (18). Pure DBA/1-strain mice were used as wild-type controls. Both wild-type and IFN $\gamma$ R-KO DBA/1 mice were bred in the Experimental Animal Centre of the Katholieke Universiteit Leuven. The experiments were performed on male 8-12-weekold mice, with age-matched male control animals used in each experiment. All animal experiments were approved by the local ethics committee.

Induction of arthritis by injection of CFA, and assessment of arthritis. For the induction of arthritis, CFA (Difco, Detroit, MI) with added heat-killed Mycobacterium butyricum $(0.5 \mathrm{mg} / \mathrm{ml}$; Difco) was emulsified in an equal volume of phosphate buffered saline (PBS) or PBS containing CII (2 $\mathrm{mg} / \mathrm{ml}$ ) from chicken sternal cartilage (Sigma-Aldrich, St. Louis, MO). IFN $\gamma \mathrm{R}-\mathrm{KO}$ and wild-type mice were sensitized with a single intradermal injection, at the tail base, of $100 \mu \mathrm{l}$ of CFA-PBS or CFA-CII on day 0. In some experiments wildtype mice were treated with neutralizing mouse antibodies (rat IgG2a) against murine IFN $\gamma$ on days 0 , 7, and 14 after sensitization with CFA, as described (12). Beginning on day 1, mice were evaluated daily for symptoms of arthritis. Disease severity in each limb was assessed on a 0-4 scale using a previously described scoring system (12), in which $0=$ normal, $1=$ redness and/or swelling in 1 joint, $2=$ redness and/or swelling in $>1$ joint, $3=$ redness and/or swelling in the entire paw, and $4=$ deformity and/or ankylosis (maximum possible total score $=16$ ).

For histologic assessment, fore limbs and hind limbs (ankles and interphalangeal joints) were fixed in 10\% formalin, decalcified with formic acid, and embedded in paraffin. Paraffin sections were stained with hematoxylin and eosin. Severity of arthritis was evaluated and scored under blinded conditions, using 3 parameters: the extent of infiltration of mononuclear and polymorphonuclear cells, the extent of hyperplasia of the synovium, and pannus formation.

TNF bioassay. To measure TNF bioactivity levels in sera, the MTT tetrazolium cytotoxicity assay (M-2128; SigmaAldrich) for fibroblasts was used as previously described (27). $\mathrm{TNF} \alpha$ concentration was determined by comparison with a standard curve. Recombinant mouse TNF $\alpha$ (National Institute for Biological Standards and Controls, London, UK) was used as a standard. One unit of $\mathrm{TNF} \alpha$ activity was defined as the amount that caused $50 \%$ destruction (i.e., $50 \%$ absorbance change) of L929 cells.

Preparation of cell suspensions and flow cytometric analysis. Spleens and bone marrow were isolated and passed through cell strainers (Becton Dickinson, Franklin Lakes, NJ) to obtain single-cell suspensions. Blood was obtained by heart puncture. Red blood cells were lysed by 1 incubation (for bone marrow cells) $\left(5\right.$ minutes at $\left.37^{\circ} \mathrm{C}\right)$ or 2 incubations (for splenocytes and blood cells) (5 minutes and 3 minutes, at $37^{\circ} \mathrm{C}$ ) with $\mathrm{NH}_{4} \mathrm{Cl}$ solution $(0.83 \%$ in $0.01 M$ Tris $\mathrm{HCl}$ [pH 7.2]). 
Remaining cells were washed twice with ice-cold PBS and resuspended in the appropriate medium for further use.

For flow cytometric analysis, single-cell suspensions $\left(5 \times 10^{5}\right.$ cells $)$ were incubated for 15 minutes with the Fc receptor blocking antibodies anti-CD16/anti-CD32 (CD16/ CD32; BD Biosciences PharMingen, San Diego, CA). Cells were washed with PBS-2\% fetal calf serum (FCS) and with the indicated fluorescein isothiocyanate (FITC)-conjugated antibodies $(0.5 \mu \mathrm{g})$ for 30 minutes, then washed twice with PBS-2\% FCS, and stained with the indicated phycoerythrin (PE)-conjugated antibodies. Finally, cells were washed and fixed with $0.37 \%$ formaldehyde in PBS. FITC-conjugated CD11b (Mac-1), FITC-conjugated B220, FITC-conjugated CD8, PE-conjugated CD115, and PE-conjugated CD4 were purchased from BD Biosciences PharMingen.

For intracellular flow cytometry, $3 \times 10^{5}$ cells in a total volume of $200 \mu \mathrm{l}$ were cultured in chamber slides and incubated for 24 hours at $37^{\circ} \mathrm{C}$. After 24 hours, appropriate stimuli (medium or $M$ butyricum [300 $\mu \mathrm{g} / \mathrm{ml}]$ ) were added. GolgiStop (2 $\mu \mathrm{g} / \mathrm{ml}$; BD Biosciences PharMingen) was added in all experiments. Cells and their appropriate stimuli were incubated for 5 hours at $37^{\circ} \mathrm{C}$ and then harvested. For intracellular staining with FITC-conjugated anti-TNF $\alpha$ (BD Biosciences PharMingen), $10^{6}$ cells were labeled with PE-conjugated antiCD11b as described above. Cells were then fixed, permeabilized, and stained with FITC-conjugated anti-TNF $\alpha$ using a Cytofix/Cytoperm kit according to the recommendations of the manufacturer (BD Biosciences PharMingen). Flow cytometric analysis was performed on a FACScan flow cytometer with CellQuest software (Becton Dickinson, San Jose, CA).

In vitro induction of osteoclast formation, tartrateresistant acid phosphatase (TRAP) staining, and pitformation assay. Splenocytes, blood cells, and bone marrow suspensions, obtained as described above, were resuspended in $\alpha$-minimum essential medium containing 10\% FCS (Gibco Invitrogen, Paisley, UK). Cells $\left(2.5 \times 10^{4}\right)$ in a total volume of $400 \mu \mathrm{l}$ were seeded in chamber slides (Lab-Tek; Nalge Nunc International, Naperville, IL). Cells were incubated for 6 days with $20 \mathrm{ng} / \mathrm{ml} \mathrm{M-CSF}$ plus $100 \mathrm{ng} / \mathrm{ml} \mathrm{RANKL}$ or $20 \mathrm{ng} / \mathrm{ml}$ TNF $\alpha$. All cytokines were obtained from R\&D Systems (Abingdon, UK). On day 6, media were removed and cells were stained for the presence of TRAP, as described previously (18). All reagents were obtained from Sigma-Aldrich. Red-staining cells were considered to contain TRAP, and TRAP + multinucleated cells ( $\geq 3$ nuclei) were defined as osteoclasts.

For the pit-formation assay, cell suspensions were obtained as described above. Cells $\left(10^{6}\right)$ were cultured for 6 days with M-CSF $(20 \mathrm{ng} / \mathrm{ml})$ and RANKL $(100 \mathrm{ng} / \mathrm{ml})$ on transparent quartz slides coated with calcium phosphate film (BioCoat Osteologic Discs; BD Biosciences PharMingen). Cells were removed, and resorption of the film was assessed by light microscopy.

PCR. Synovial tissue from the ankle joints was isolated under a manual stereomicroscope. Total RNA was extracted using the Micro-to-Midi Total RNA Purification System in accordance with the instructions of the manufacturer (Invitrogen Life Technologies, Carlsbad, CA). Complementary DNA was obtained by reverse transcription (RT) using Superscript II reverse transcriptase and random primers as recommended by the manufacturer (Invitrogen Life Technologies). For real- time RT-PCR, we used a TaqMan Assay-on-Demand gene expression product (Applied Biosystems, Foster City, CA). Levels of expression of RANKL, OPG, and TNF $\alpha$ (assay ID Mm00441908_m1, Mm00435452_m1, and Mm00443258_m1, respectively; Applied Biosystems) were normalized to expression of 18S RNA (catalog no. 4319413E; Applied Biosystems). Analysis was performed with an ABI Prism 7000 apparatus (Applied Biosystems), under the following conditions: inactivation of possible contaminating amplicons with AmpErase UNG for 2 minutes at $50^{\circ} \mathrm{C}$, initial denaturation for 10 minutes at $95^{\circ} \mathrm{C}$, followed by 40 thermal cycles of 15 seconds at $95^{\circ} \mathrm{C}$ and 90 seconds at $60^{\circ} \mathrm{C}$. Relative gene expression was assessed using the $2^{-\Delta \Delta C t}$ method (28).

Treatment with etanercept. For administration of etanercept, Alzet osmotic minipumps (model 2004; Durect, Cupertino, CA) were implanted subcutaneously in the dorsolateral area of the body. During the procedure, the mice were anesthetized with a solution of PBS containing $0.2 \%$ Rompun (Bayer, Brussels, Belgium) and 1\% Ketalar (Parke-Davis, Zaventem, Belgium). The minipumps were filled according to the instructions of the manufacturer and delivered etanercept at a constant rate of $125 \mu \mathrm{g} /$ day for 28 days. The efficacy of etanercept in inhibiting mouse $\mathrm{TNF} \alpha$ was verified: $2.5 \mathrm{mg} / \mathrm{ml}$ etanercept was able to prevent $10^{5}$ units $/ \mathrm{ml}$ mouse TNF $\alpha$ bioactivity in the TNF $\alpha$ bioassay.

Administration of anti-CD4 antibodies. Rat antimouse depleting antibodies (rat IgG2b) against murine CD4 were purified from culture supernatants of hybridoma GK1.5 (TIB-207; American Type Culture Collection, Manassas, VA) as previously described (29). Anti-CD4 antibodies (0.5 ml) were injected intraperitoneally twice per week, starting 1 day before sensitization with CFA.

\section{RESULTS}

Induction of arthritis in IFN $\gamma \mathrm{R}-\mathrm{KO}$ mice by CFA. In an initial experiment, only IFN $\gamma \mathrm{R}-\mathrm{KO} \mathrm{DBA} / 1$ mice were used. The mice received a single intradermal injection of CFA containing heat-killed $M$ butyricum on day 0 and were examined daily for symptoms of arthritis. For comparison with CIA, a group of IFN $\gamma \mathrm{R}-\mathrm{KO}$ mice immunized with CII in CFA was included. Redness and swelling of the joints started to appear 2 days earlier in mice with CIA compared with mice injected with CFA alone (day 14 versus day 16). During the time course of the experiment, $42 \%$ of the mice injected with CFA alone developed arthritis, whereas $100 \%$ of the mice with CIA did (Figure 1A). Figure 1B shows the mean arthritis scores in diseased animals. In contrast to CIA, the clinical symptoms of arthritis in CFAinjected mice were transient, peaking on day 17-18 and then gradually decreasing in severity (Figure 1B). The maximal mean arthritis score in diseased mice immunized with CII in CFA was higher than that in mice treated with CFA alone (mean \pm SEM $8.7 \pm 0.6$ versus $4.0 \pm 1.2)$. 


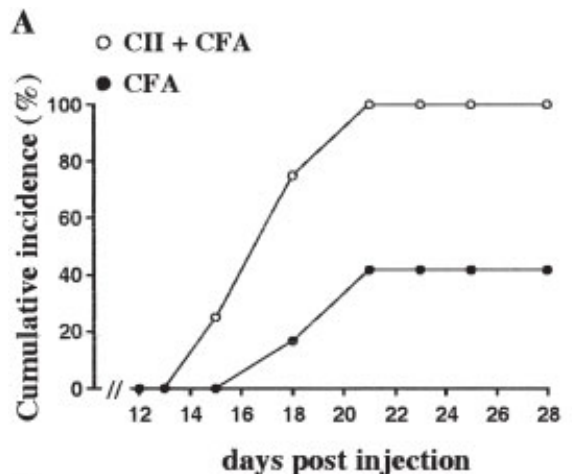

C

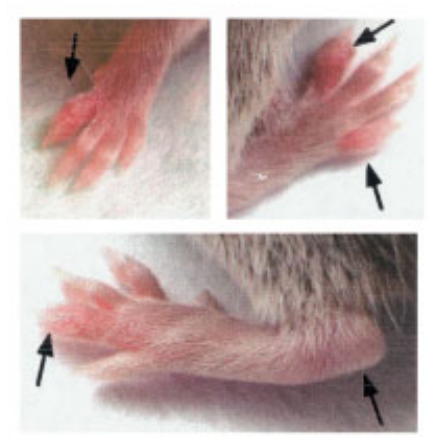

B

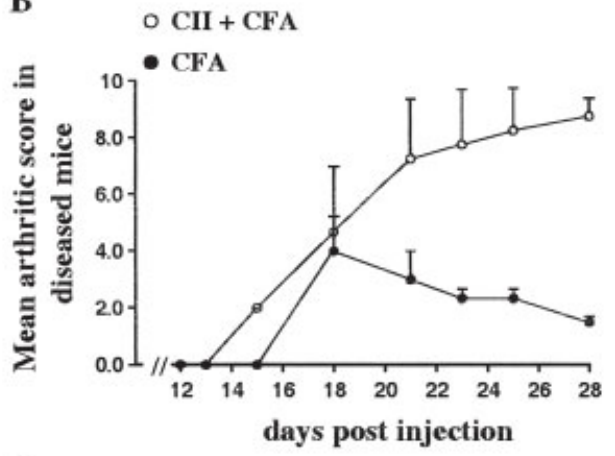

D

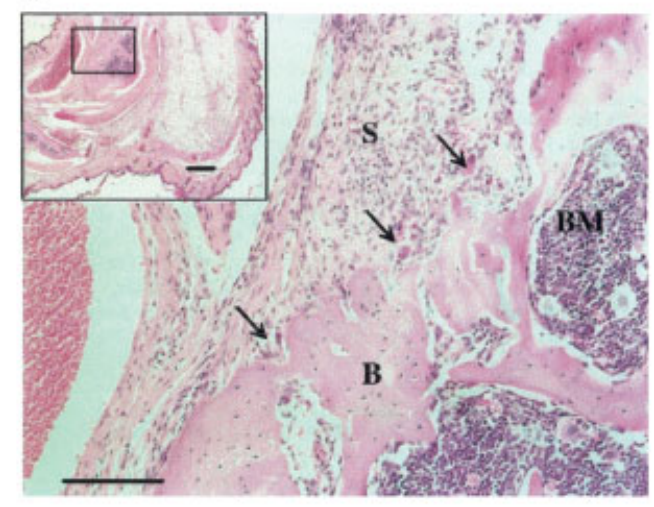

Figure 1. Induction of adjuvant arthritis in interferon- $\gamma$ receptor-knockout (IFN $\gamma \mathrm{R}-\mathrm{KO}$ ) DBA/1 mice. Mice were administered a single intradermal injection of Freund's complete adjuvant (CFA) or type II collagen (CII) in CFA on day 0, and were examined daily for symptoms of arthritis. A and $\mathbf{B}$, Cumulative incidence of arthritis (A) and arthritis scores in diseased mice (B) during the time course of the experiment (maximum possible arthritis score $=16$ ). Values in $\mathbf{B}$ are the mean and SEM from 1 representative experiment of 5 independent experiments performed. C, Representative photographs showing joint inflammation in the fore limb (upper left photograph) and hind limb (upper right and lower photographs) on day 26 after CFA challenge in IFN $\gamma \mathrm{R}-\mathrm{KO}$ mice. Redness and swelling of the toes is evident (arrows). D, Hematoxylin and eosin-stained section of the ankle of an IFN $\gamma \mathrm{R}-\mathrm{KO}$ mice killed 26 days after injection of CFA. Hyperplasia of the synovial cells, infiltration of the synovium (S) with mononuclear and polymorphonuclear cells, and destruction of bone (B) can be seen. Note the presence of osteoclast-like multinucleated giant cells (arrows). $\mathbf{B M}=$ bone marrow. The large photograph is a detail of the area indicated by the box in the inset. Bars $=25 \mu \mathrm{m}$.

Figure 1C shows representative images of the inflamed joints of CFA-sensitized mice. Both fore limbs and hind limbs were affected. In additional experiments, in which a similar course of arthritis was observed after CFA sensitization, mice were killed on day 26 for histologic evaluation of the joints. Hematoxylin and eosin staining revealed mononuclear and polymorphonuclear cell infiltration into the synovium, together with hyperplasia of synovial tissue, pannus formation, and destruction of bone by multinucleated osteoclasts. Hyperplasia and bone destruction by osteoclasts were observed in the early phase of disease (day 26) (Figure 1D) and remained present in the late phase (results not shown). In contrast, infiltration of the synovium with inflammatory cells was especially pronounced during the early phase and diminished thereafter.

The development of CFA-induced arthritis in IFN $\gamma \mathrm{R}-\mathrm{KO} \mathrm{DBA} / 1$ mice was confirmed in 4 additional experiments. In total, 23 of the 42 IFN $\gamma \mathrm{R}-\mathrm{KO}$ mice that were injected with CFA (55\%) developed arthritis, compared with 11 of the 13 IFN $\gamma \mathrm{R}-\mathrm{KO}$ mice immunized with CII in CFA (85\%). Moreover, wild-type mice pretreated with anti-IFN $\gamma$ antibody also developed CFA-induced arthritis, whereas this was not the case without antibody treatment (data not shown). In fact, wild-type mice were quite resistant to CFA-induced 
arthritis: only 1 of $20(5 \%)$ developed symptoms (redness and swelling in 1 hind limb on day 38). Of note, a spontaneous form of arthritis has been described to occur in older DBA/1 mice housed in groups derived from different litters (30). In our experiments, the occurrence of spontaneous arthritis was limited by using mice that were $<4$ months old and by not mixing mice from different litters.

Importantly, arthritis was also successfully induced by CFA treatment in BALB/c mice in which the IFN $\gamma$ gene had been deleted. IFN $\gamma$-KO BALB/c mice (31) developed CFA-induced arthritis within 3 weeks, with a rather high incidence $(50 \%$ and $77.8 \%$ in 2 experiments, with 10 mice and 16 mice, respectively), whereas arthritis did not develop in wild-type BALB/c mice after CFA injection.

Development of CFA-induced arthritis coincides with expansion of the CD11b+ cell population in the spleen. The development of adjuvant arthritis in rats has been described to be associated with the occurrence of inflammatory lesions in several organs, lupus-like symptoms, and granuloma formation (32). Therefore, in a series of experiments, mice challenged with CFA were killed for histologic examination. Thyroid, kidney, pancreas, lung, liver, heart, intestine, and lymph nodes were found to be free of histologic abnormalities. Of note, anti-DNA antibodies were not detectable in the sera of CFA-injected IFN $\gamma \mathrm{R}-\mathrm{KO}$ mice (data not shown). Spleens of CFA-injected mice were significantly enlarged (Figure 2A): the mean \pm SEM spleen weights of CFA-injected and nonsensitized mice were $159 \pm 9 \mathrm{mg}$ $(\mathrm{n}=4)$ and $85 \pm 5 \mathrm{mg}(\mathrm{n}=5)$, respectively. Morphologic analysis revealed that red pulp was extensively expanded due to extreme extramedullary hematopoiesis (results not shown).

The total number of splenocytes was higher in CFA-injected mice than in naive mice. Flow cytometric analysis revealed larger numbers of CD11b + myeloid cells in the spleens of CFA-sensitized mice, while the numbers of CD4+ and CD8+ T cells and B220+ cells were comparable with those in the spleens of nonsensitized mice (Figures 2B and C). Much like the clinical symptoms of arthritis, the expansion of the CD11b + cell population was transient and peaked between days 17 and 25 (data not shown). In IFN $\gamma \mathrm{R}-\mathrm{KO}$ mice, the increase in the number of $\mathrm{CD} 11 \mathrm{~b}+$ splenocytes was significantly more pronounced compared with the increase in wild-type mice; for example, on day 25 , the mean \pm SEM number of CD11b + splenocytes in CFAinjected IFN $\gamma \mathrm{R}-\mathrm{KO}$ and wild-type mice, respectively,
A

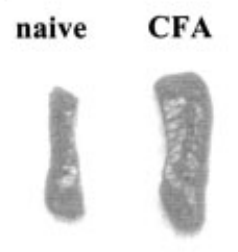

C
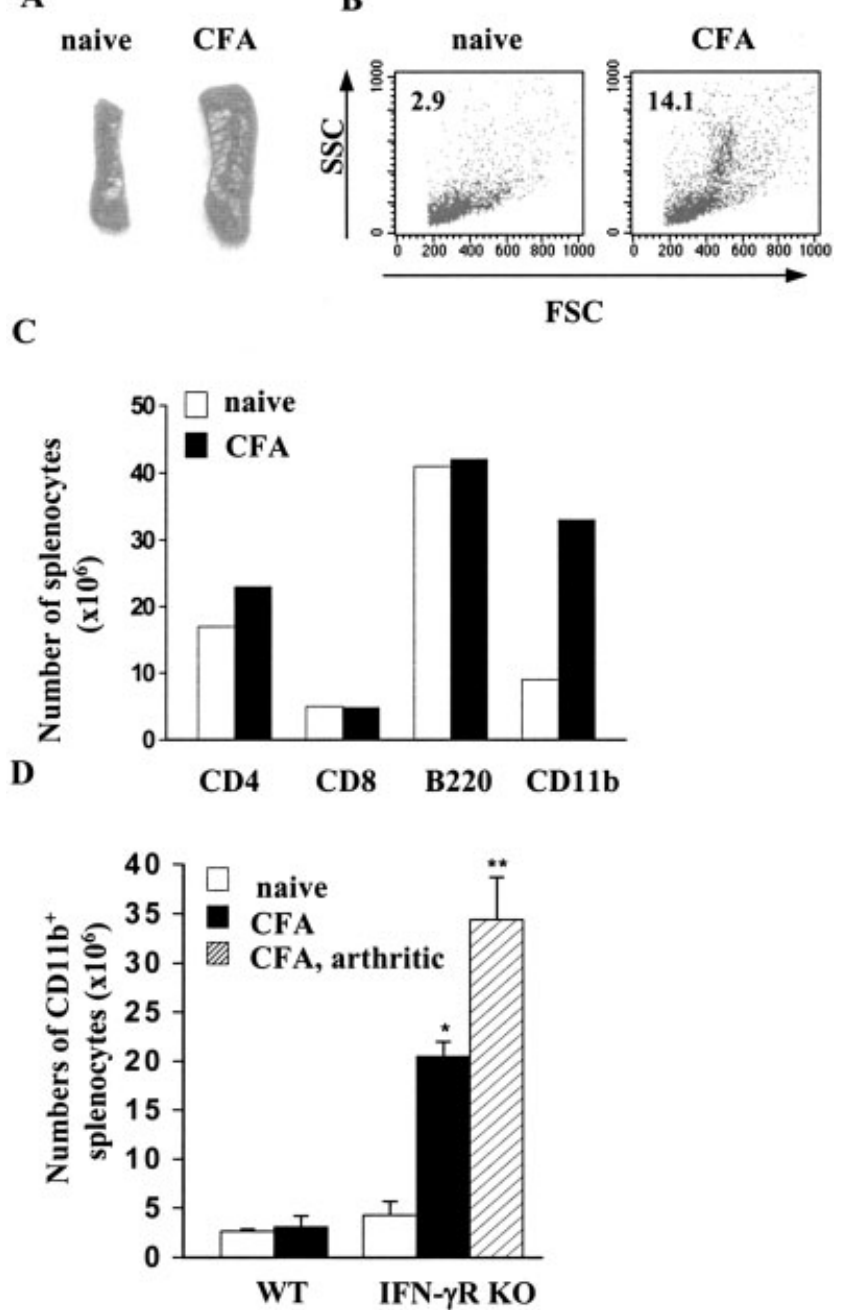

Figure 2. Expansion of the CD11b + cell population in the spleens of mice with CFA-induced arthritis. Mice were either left untreated or were administered a single intradermal injection of CFA. On day 23 after sensitization, splenocytes were isolated, counted, and pooled for flow cytometric analysis as described in Materials and Methods. A, Spleens of representative naive and CFA-injected IFN $\gamma \mathrm{R}-\mathrm{KO}$ mice, showing substantial enlargement after CFA treatment. B, Flow cytometry (forward scatter [FSC] and side scatter [SSC]) of splenocytes from naive and CFA-challenged IFN $\gamma \mathrm{R}-\mathrm{KO}$ mice (pooled splenocytes from 3 randomly selected mice per group). Numbers are the percent of splenocytes expressing CD11b. C, CD4+, CD $8+, \mathrm{B} 220+$, and $\mathrm{CD} 11 \mathrm{~b}+$ splenocyte populations in naive and CFA-treated IFN $\gamma \mathrm{R}-\mathrm{KO}$ mice. Splenocytes were obtained from 3 mice per group, counted, and pooled for flow cytometric analysis. Only the CD11b+ population was expanded in CFA-treated mice compared with nonsensitized mice. D, Numbers of CD11b + splenocytes in naive and CFA-treated wild-type (WT) mice and in naive, CFA-treated arthritic, and CFA-treated nonarthritic IFN $\gamma \mathrm{R}-\mathrm{KO}$ mice. Splenocytes were isolated on day 21 post-CFA treatment. Values are the mean and SEM from 2 experiments. $*=P<0.05$ versus naive IFN $\gamma \mathrm{R}-\mathrm{KO}$ mice; $* *=P<0.01$ versus nonarthritic CFA-treated IFN $\gamma \mathrm{R}-\mathrm{KO}$ mice. See Figure 1 for other definitions. 
A

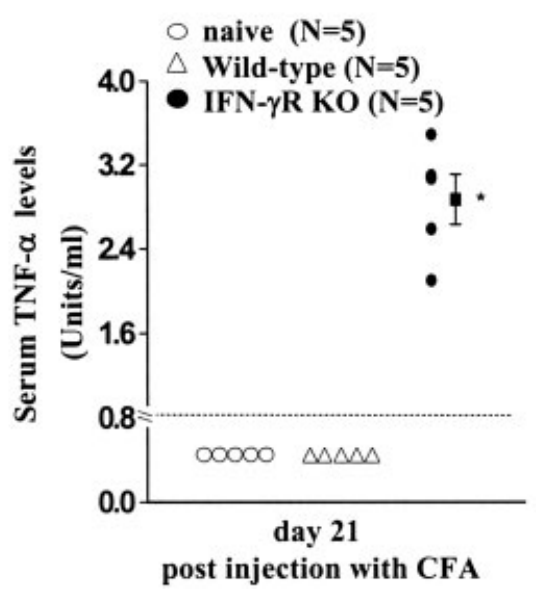

B

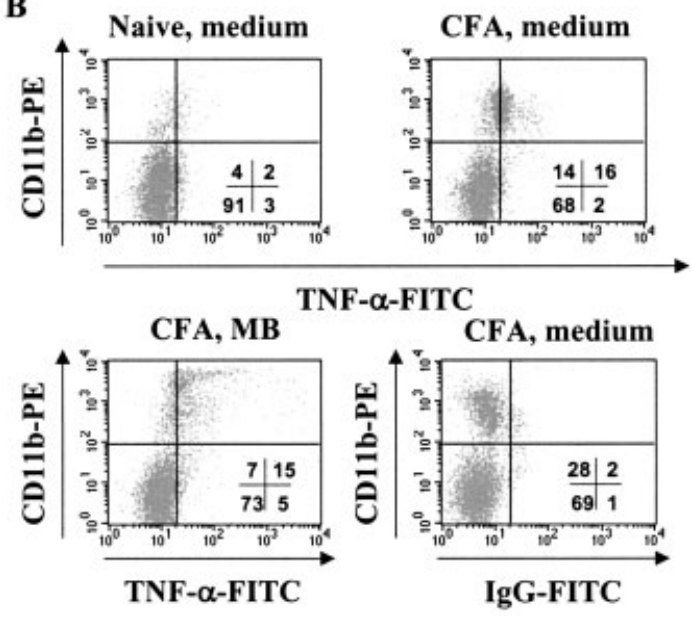

Figure 3. Elevated serum levels of tumor necrosis factor $\alpha(\mathrm{TNF} \alpha)$ in Freund's complete adjuvant (CFA)-challenged interferon- $\gamma$ receptor-knockout (IFN $\gamma \mathrm{R}-\mathrm{KO}$ ) mice. A, TNF $\alpha$ levels in serum samples from naive, CFA-treated wild-type, and CFA-treated IFN $\gamma$ R-KO mice. On day 21 after injection of CFA, blood was collected and TNF $\alpha$ levels were measured as described in Materials and Methods. One of the 5 IFN $\gamma \mathrm{R}-\mathrm{KO}$ mice exhibited symptoms of arthritis. Values in individual mice, and the mean \pm SEM in CFA-treated IFN $\gamma \mathrm{R}-\mathrm{KO}$ mice (square and bars), are shown. $*=P<0.01$ versus naive mice and CFA-injected wild-type mice, by Mann-Whitney U test. B, TNF $\alpha$ production by $\mathrm{CD} 11 \mathrm{~b}+$ cells from CFA-injected mice, and increase upon stimulation with Mycobacterium butyricum (MB). Intracellular staining with fluorescein isothiocyanate (FITC)-conjugated anti-TNF $\alpha$ was performed as described in Materials and Methods. Results shown are from 1 representative experiment of 3 experiments performed. Upper plots show the staining patterns of unstimulated splenocytes from naive and CFA-injected mice. Lower left plot shows the pattern after splenocytes from CFA-injected mice had been stimulated for 5 hours with $M$ butyricum. Lower right plot shows the pattern obtained using an isotype control antibody (FITC-conjugated $\operatorname{IgG}$ ), verifying the specificity of TNF $\alpha$ staining. Numbers are the percent of cells in each quadrant. $\mathrm{PE}=$ phycoerythrin.

was $21 \pm 3 \times 10^{6}$ and $4 \pm 1 \times 10^{6}(\mathrm{n}=3$ mice per group) $(P<0.05)$.

Since only $55 \%$ of CFA-sensitized IFN $\gamma \mathrm{R}-\mathrm{KO}$ mice developed symptoms of arthritis, we examined whether the CD11b + expansion might be different in mice that developed arthritis versus those that remained free of symptoms. Ten IFN $\gamma \mathrm{R}-\mathrm{KO}$ mice were injected with CFA, and symptoms of arthritis were recorded. On day 21 post-CFA injection, 5 mice had developed arthritis whereas 5 remained free of symptoms, and all animals were killed for analysis. The weight of the spleen was significantly higher in arthritic versus nonarthritic mice (mean \pm SEM $182.7 \pm 3.5 \mathrm{mg}$ versus $142.3 \pm 3.2 \mathrm{mg}$; $\mathrm{n}=5$ per group) $(P<0.05)$, as was the number of $\mathrm{CD} 11 \mathrm{~b}+$ splenocytes $\left(42 \pm 5 \times 10^{6}\right.$ versus $\left.23 \pm 1 \times 10^{6}\right)$ $(P<0.05)$. The difference in the expansion of CD11b+ splenocytes between arthritic and nonarthritic IFN $\gamma \mathrm{R}-\mathrm{KO}$ mice was confirmed in an additional experiment, and the results of the 2 experiments are depicted in Figure 2D. The results showed that CFA induced expansion of $\mathrm{CD} 11 \mathrm{~b}+$ splenocytes only in IFN $\gamma \mathrm{R}-\mathrm{KO}$ mice, and the expression was more pronounced in animals that developed symptoms of arthritis.

Spontaneous production of TNF $\alpha$ by CD11b+ cells and increased osteoclastogenesis from splenocytes and blood leukocytes of CFA-challenged IFN $\gamma \mathrm{R}-\mathrm{KO}$ mice. An expansion of peripheral CD11b + cells in $\mathrm{TNF} \alpha$-transgenic mice with spontaneously developing arthritis has recently been described (24). The expanding cells consisted of osteoclast precursor cells, and the joint destruction could be counteracted by targeting osteoclasts (33). In the present study we investigated $\mathrm{TNF} \alpha$ production and the osteoclastogenic potential of spleen and blood cells from mice with CFA-induced arthritis. We detected bioactive $\mathrm{TNF} \alpha$ in the serum of CFA-sensitized IFN $\gamma \mathrm{R}-\mathrm{KO}$ mice, whereas it was undetectable in serum from CFA-injected wild-type mice or from naive mice (Figure 3A).

Since $\mathrm{TNF} \alpha$ is a natural product of activated macrophages, we investigated whether the expanding population of $\mathrm{CD} 11 \mathrm{~b}+$ splenocytes could be a source of TNF $\alpha$ in our model. For this purpose, flow cytometric 
$\mathbf{A}$

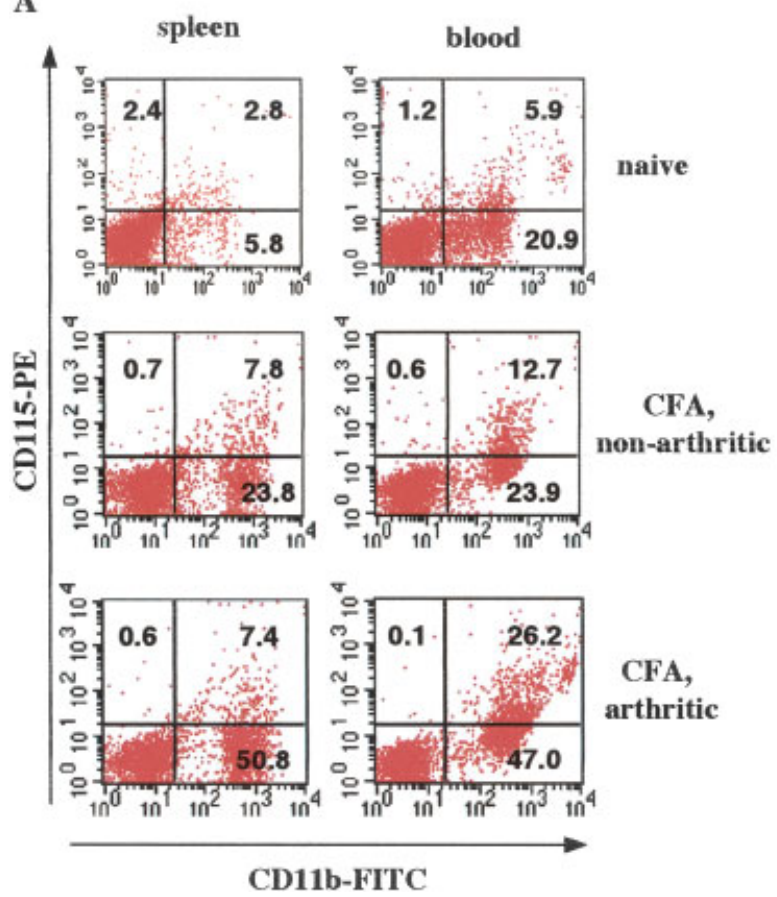

B
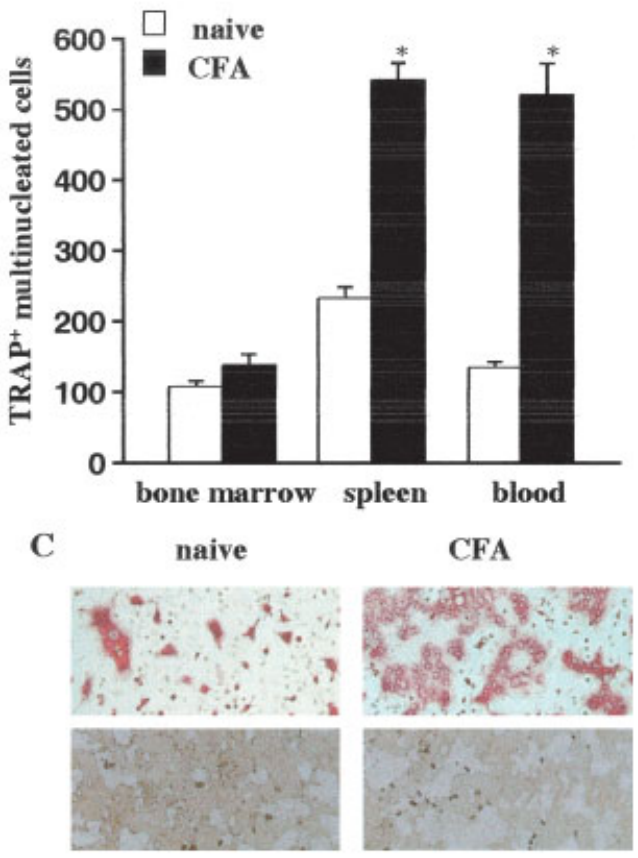

Figure 4. Increased osteoclastogenesis from splenocytes and blood leukocytes of CFA-challenged IFN $\gamma \mathrm{R}-\mathrm{KO}$ mice. Mice were either left untreated or administered a single intradermal injection of CFA. Bone marrow, splenocytes, and blood cells were isolated as described in Materials and Methods. Values shown are from day 23 after sensitization. A, Representative flow cytometric analyses of $\mathrm{CD} 11 \mathrm{~b}+, \mathrm{CD} 115+$ cells among splenocytes and white blood cells. Numbers are the percent of cells in each quadrant. B, Numbers of tartrate-resistant acid phosphatase (TRAP)-positive multinucleated cells ( $\geq 3$ nuclei) in bone marrow, spleen, and blood. Bone marrow, splenocytes, and blood cells were cultured for 6 days in medium containing $20 \mathrm{ng} / \mathrm{ml}$ macrophage colony-stimulating factor plus $100 \mathrm{ng} / \mathrm{ml}$ RANKL. After stimulation, cultures were fixed and stained for the presence of TRAP. Values are the mean and SEM from 4 CFA-treated mice ( 2 arthritic and 2 nonarthritic) and 4 naive mice. $*=P<0.05$ versus naive mice, by Mann-Whitney U test. C, Representative photomicrographs of TRAP-stained cultures of splenocytes (upper panels) and resorption pits (lower panels) (magnification $\times 40$ ). See Figure 3 for other definitions.

analysis was performed using extracellular staining with PE-conjugated CD11b antibodies in combination with intracellular staining with FITC-conjugated TNF $\alpha$ antibodies. To increase the sensitivity of this cytokine detection procedure, cells were cultured for 5 hours in the presence of GolgiStop. Splenocytes from CFAsensitized and nonsensitized IFN $\gamma \mathrm{R}-\mathrm{KO}$ mice were cultured either without stimulation or with $M$ butyricum stimulation.

Typical examples of CD11b and $\mathrm{TNF} \alpha$ staining are shown in Figure 3B. Splenocytes from naive mice included virtually no $\mathrm{TNF} \alpha$-containing cells. However, among splenocytes derived from CFA-sensitized mice, $\mathrm{TNF} \alpha$-positive cells were detectable, mainly in the expanding CD11b + subpopulation. The specificity of the $\mathrm{TNF} \alpha$ staining was verified using an isotype control antibody. Stimulation of these splenocytes with M butyri- cum did not increase the numbers of TNF $\alpha$-producing $\mathrm{CD} 11 \mathrm{~b}+$ cells but did increase the amount of TNF $\alpha$ produced per cell, as evident from the increase in mean fluorescence intensity ( 25 in unstimulated cells versus 149 after stimulation with $M$ butyricum).

To ascertain whether $\mathrm{TNF} \alpha$ production differs between CFA-injected arthritic and CFA-injected nonarthritic IFN $\gamma \mathrm{R}-\mathrm{KO}$ mice, we measured serum $\mathrm{TNF} \alpha$ levels and analyzed $\mathrm{TNF} \alpha$ expression in $\mathrm{CD} 11 \mathrm{~b}+$ spleen cells. The results revealed no significant difference between the 2 groups of CFA-injected IFN $\gamma \mathrm{R}-\mathrm{KO}$ mice in terms of $\mathrm{TNF} \alpha$ production or $\mathrm{TNF} \alpha$ expression in $\mathrm{CD} 11 \mathrm{~b}+$ cells (data not shown).

We determined, by flow cytometry, the number of $\mathrm{CD} 11 \mathrm{~b}+, \mathrm{CD} 115+$ double-positive cells since this population of cells has recently been identified as a population of osteoclast precursors $(24,34)$, and we 
A

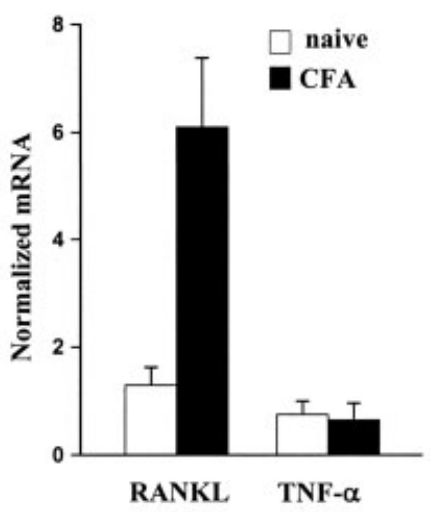

B

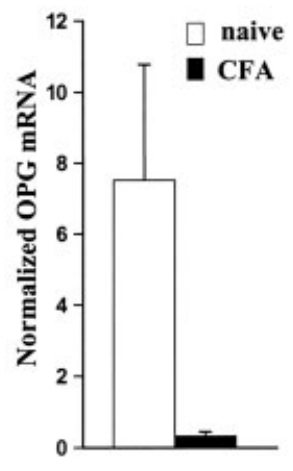

C

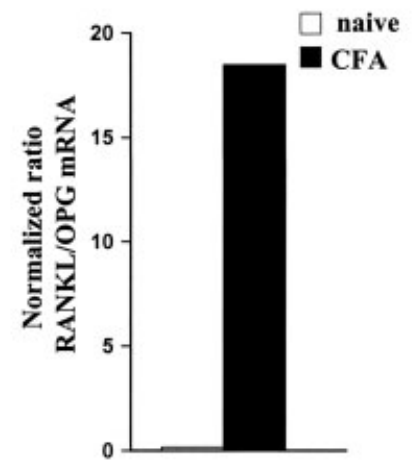

D
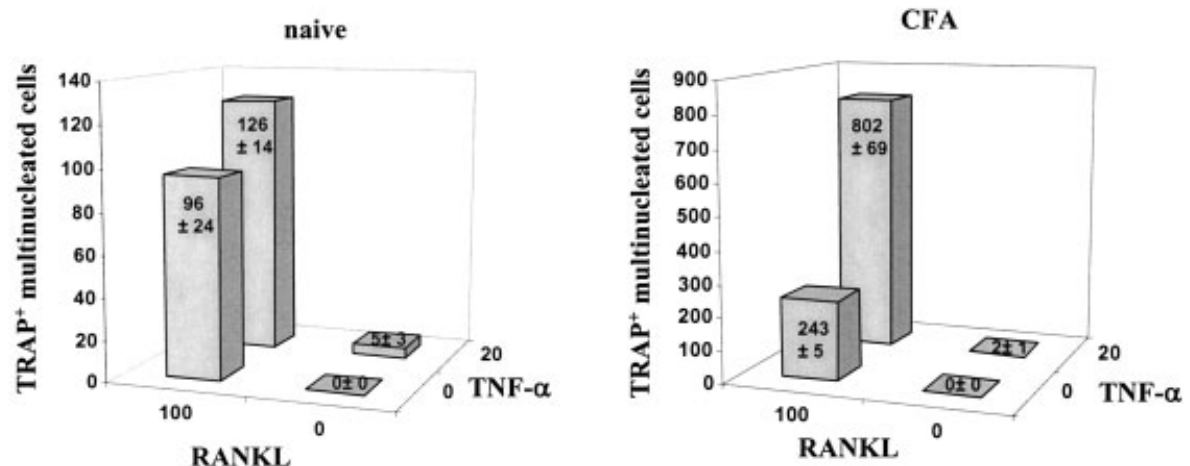

Figure 5. RANKL, TNF $\alpha$, and osteoprotegerin (OPG) mRNA levels in joints of IFN $\gamma \mathrm{R}-\mathrm{KO}$ mice that were administered a single intradermal injection of CFA, and synergistic activity of RANKL and TNF $\alpha$. A-C, Quantitative reverse transcriptase-polymerase chain reaction was performed on cDNA from isolated synovia of 3 sensitized (day 29 post-sensitization) and 2 nonsensitized IFN $\gamma \mathrm{R}-\mathrm{KO}$ mice, and transcription of RANKL and TNF $\alpha(\mathbf{A})$ and OPG (B), and the RANKL:OPG transcription ratio (C) within the synovium were determined. Relative quantities of mRNA were normalized to the levels of 18S RNA in the samples. Values are the mean and SEM. D, To assess the synergistic action of TNF $\alpha$ and RANKL on osteoclastogenesis, splenocytes were cultured for 6 days in the presence of the indicated stimuli $(100 \mathrm{ng} / \mathrm{ml}$ RANKL or $20 \mathrm{ng} / \mathrm{ml} \mathrm{TNF} \alpha$, plus $20 \mathrm{ng} / \mathrm{ml}$ macrophage colony-stimulating factor). After stimulation, cultures were fixed and stained for the presence of tartrate-resistant acid phosphatase (TRAP). TRAP+ multinucleated cells ( $\geq 3$ nuclei) were counted in each cup. Numbers shown in the bars are the mean \pm SEM from 4 mice. See Figure 3 for other definitions.

studied RANKL/M-CSF-induced osteoclast formation in cultures of bone marrow, splenocytes, and blood cells derived from CFA-injected arthritic and nonarthritic IFN $\gamma \mathrm{R}-\mathrm{KO}$ mice as well as from naive animals. A representative $\mathrm{CD} 11 \mathrm{~b} / \mathrm{CD} 115$ staining pattern in spleen and blood cells is shown in Figure 4A. A mild expansion of $\mathrm{CD} 11 \mathrm{~b}+, \mathrm{CD} 115+$ cells could be seen in spleen cells from CFA-injected mice, without any difference between arthritic and nonarthritic animals. In contrast, the percentage of $\mathrm{CD} 11 \mathrm{~b}+, \mathrm{CD} 115+$ cells in blood was higher in arthritic versus nonarthritic animals, and the difference was found to be significant (mean \pm SEM
$26 \pm 0.5 \%$ versus $13 \pm 0.5 \% ; \mathrm{n}=5$ per group $)(P<$ $0.01)$.

To further confirm that the spleen and blood of sensitized IFN $\gamma \mathrm{R}-\mathrm{KO}$ mice indeed contained a higher proportion of osteoclast precursors, spleen and blood cells were cultured for 6 days in medium containing M-CSF plus RANKL, followed by TRAP staining. Significantly higher numbers of TRAP + multinucleated osteoclasts were generated in cultures of splenocytes and blood cells derived from CFA-treated IFN $\gamma \mathrm{R}-\mathrm{KO}$ mice than in those from naive mice (Figure 4B). Moreover, TRAP + osteoclasts that were generated from CFA- 
injected animals were larger in size and contained more nuclei than osteoclasts generated from naive mice (Figure 4C). The effect of CFA sensitization on increased osteoclast formation was not observed in bone marrow cultures (Figure 4B).

To verify the activity of the generated osteoclasts, splenocytes from sensitized and nonsensitized IFN $\gamma \mathrm{R}-\mathrm{KO}$ mice were cultured on quartz substrate and coated with calcium phosphate film in the presence of RANKL plus M-CSF, and pit formation was quantified. The total number of pits appeared to be higher in splenocyte cultures derived from the sensitized mice. Moreover, pits with a large surface area $\left(>5,000 \mu \mathrm{m}^{2}\right)$ were more frequent in such cultures (Figure 4C).

Production of RANKL, TNF $\alpha$, and OPG in arthritic joints, and synergistic activity of RANKL and TNF $\boldsymbol{\alpha}$. To test whether stimuli for osteoclast differentiation were present at the site of inflammation, quantitative RT-PCR for RANKL and TNF $\alpha$ was performed on isolated synovia of sensitized and nonsensitized IFN $\gamma$ R-KO mice. Quantification of OPG, a decoy receptor for RANKL (35), was included in the RT-PCR. From the data shown in Figure 5, it can be seen that the number of RANKL messenger RNA (mRNA) copies increased upon challenge with CFA (Figure 5A). More importantly the number of OPG mRNA copies was found to be 25 times lower in the synovia of CFAchallenged mice than in those of naive mice (Figure 5B). Injection of IFN $\gamma \mathrm{R}-\mathrm{KO}$ mice with CFA resulted in a 108-fold increase in the RANKL:OPG ratio (Figure 5C). TNF $\alpha$ mRNA was found to be present in the synovia of CFA-challenged mice, but the numbers of mRNA copies were not different from those in naive mice (Figure 5A).

Because both RANKL and TNF $\alpha$ are present in the synovium, we investigated whether they act synergistically on osteoclastogenesis in our model. Splenocytes from naive and CFA-injected IFN $\gamma \mathrm{R}-\mathrm{KO}$ mice were cultured for 6 days in medium containing M-CSF plus RANKL and/or TNF $\alpha$, followed by staining for TRAP. Figure 5D shows a strong synergistic effect of TNF $\alpha$ and RANKL in splenocyte cultures from CFA-challenged IFN $\gamma \mathrm{R}-\mathrm{KO}$ mice compared with naive mice, in which only a weak synergistic effect was detected.

Inhibition of CFA-induced arthritis and systemic osteoclastogenesis by etanercept treatment. The strong synergistic effect of $\mathrm{TNF} \alpha$ and RANKL on in vitro osteoclastogenesis (Figure 5D) and the presence of bioactive TNF $\alpha$ in the circulation of CFA-treated mice (Figure 3A) prompted us to investigate the effect of etanercept, a TNF $\alpha$ antagonist, on the pathogenesis of CFA-induced arthritis. CFA-sensitized IFN $\gamma \mathrm{R}-\mathrm{KO}$ mice
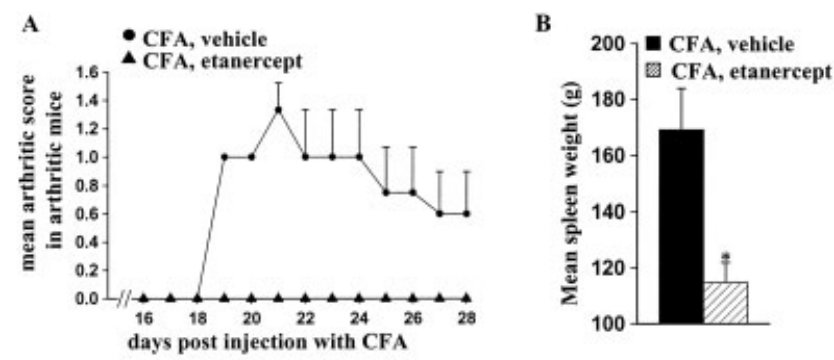

D
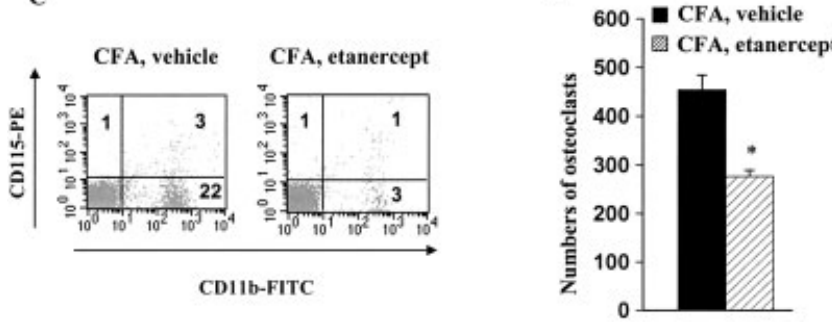

Figure 6. Inhibition of CFA-induced arthritis and systemic osteoclastogenesis by etanercept. Eight CFA-sensitized IFN $\gamma \mathrm{R}-\mathrm{KO}$ mice were implanted (day 0) with osmotic minipumps releasing etanercept at a constant rate of $125 \mu \mathrm{g} /$ day, or with minipumps delivering vehicle. A, Mean and SEM arthritis scores in diseased mice. B, Mean and SEM spleen weight of mice killed on day 29. $*=P<0.05$ versus vehicle-treated mice, by Mann-Whitney U test. C, Decrease in the $\mathrm{CD} 11 \mathrm{~b}+$ cell population in the blood of etanercept-treated IFN $\gamma \mathrm{R}-\mathrm{KO}$ mice. Blood was collected on day 29 after injection of CFA. White blood cells were stained for the presence of CD11b and CD115. Numbers are the percent of splenocytes expressing CD11b or $\mathrm{CD} 115$. The CD11b + cell population was found to represent $25 \%$ of the cells in the blood of CFA-sensitized vehicle-treated mice, but only $4 \%$ of the cells in the blood of CFA-sensitized etanercept-treated mice. D, Mean and SEM number of osteoclasts (tartrate-resistant acid phosphatase [TRAP]-positive multinucleated cells [ $\geq 3$ nuclei]). Blood cells of 4 vehicle-treated and 4 etanercept-treated CFA-sensitized IFN $\gamma \mathrm{R}-\mathrm{KO}$ mice were stimulated for 6 days with macrophage colonystimulating factor $(20 \mathrm{ng} / \mathrm{ml})$ and RANKL $(100 \mathrm{ng} / \mathrm{ml})$, and stained for the presence of TRAP. TRAP + multinucleated cells were counted in each cup. $*=P<0.05$ versus vehicle-treated mice, by Mann-Whitney $\mathrm{U}$ test. See Figure 3 for other definitions.

were implanted (day 0) with osmotic minipumps releasing etanercept at a constant rate of $125 \mu \mathrm{g} /$ day. Mice in the control group were implanted with osmotic minipumps delivering vehicle (sterile water). The minipumps have been described to be active for 28 days.

Figure 6A shows the mean arthritis scores in diseased mice in both groups during the time course of the experiment. Clinical symptoms started to appear on day 19 in the control group, but remained absent in the etanercept-treated group. Even beyond day 28, all etanercept-treated mice remained free of symptoms. The mean weight of the spleens of treated mice was significantly lower than that of controls (mean \pm SEM 
$114 \pm 7 \mathrm{mg}$ versus $169 \pm 14 \mathrm{mg}[\mathrm{n}=4$ per group]) (Figure 6B). Flow cytometric analysis of blood leukocytes showed that treated mice had fewer CD11b + cells (Figure 6C).

In view of the prophylactic therapeutic effect of etanercept on arthritis symptoms, we then tested whether this effect was due to decreased osteoclastogenesis. In vitro osteoclastogenesis assays were performed on blood cells and splenocytes from etanercept-treated and control CFA-sensitized IFN $\gamma \mathrm{R}-\mathrm{KO}$ mice. Complete blood leukocytes and whole splenocyte suspensions were cultured for 6 days in medium containing M-CSF plus RANKL. On day 7, osteoclast differentiation was evaluated by TRAP staining. As evidenced in Figure 6D, significantly lower numbers of osteoclasts appeared in the total blood leukocyte cultures from etanercepttreated CFA-sensitized mice than in those from control CFA-sensitized mice. In addition, significantly lower numbers of osteoclasts appeared in splenocyte cultures derived from etanercept-treated mice than in cultures from non-etanercept-treated CFA-sensitized controls (data not shown).

Inhibition of arthritis and expansion of CD11b+ cells by treatment with anti-CD4 antibodies. The data obtained in the experiments described above demonstrate that the arthritis induced in IFN $\gamma \mathrm{R}-\mathrm{KO}$ mice by a single intradermal injection of CFA is primarily a myeloid cell- and TNF $\alpha$-driven disease. Since lymphocytes are important activators of myeloid cells, we investigated the involvement of $\mathrm{CD} 4+\mathrm{T}$ cells in the disease process, by treating IFN $\gamma \mathrm{R}-\mathrm{KO}$ mice with $\mathrm{CD} 4$-depleting antibodies $(\mathrm{n}=7)$ or control rat $\operatorname{IgG}$ antibodies $(\mathrm{n}=10)$ starting 1 day before sensitization with CFA. Mice received an injection of anti-CD4 or control antibodies twice weekly. Flow cytometric analysis revealed $98 \%$ depletion of CD4+ cells in blood after 2 injections of anti-CD4 antibodies. Three weeks after challenge with CFA, 5 of 10 control-treated mice developed arthritis. Arthritis symptoms did not appear in anti-CD4-treated mice.

To test whether the absence of symptoms in the anti-CD4-treated mice might be related to differences in the expansion of CD11b + cells, flow cytometric analysis was performed on spleen and blood cells. Interestingly, anti-CD4-treated mice had fewer CD11b+ splenocytes (mean \pm SEM $16 \pm 1 \times 10^{6}$ ) than did arthritic control-treated mice $\left(27 \pm 5 \times 10^{6}\right)$. In fact, the numbers of $\mathrm{CD} 11 \mathrm{~b}+$ splenocytes in anti-CD4-treated mice were identical to those seen in nonarthritic IFN $\gamma \mathrm{R}-\mathrm{KO}$ mice $\left(16 \pm 1 \times 10^{6}\right)$. Likewise, the percentage of $\mathrm{CD} 11 \mathrm{~b}+, \mathrm{CD} 115+$ osteoclast precursor cells in blood was found to be significantly decreased in antiCD4-treated mice compared with control-treated animals $(9 \pm 1 \%$ versus $26 \pm 0.5 \%$ [n $=5$ per group] $)(P<$ $0.01)$.

\section{DISCUSSION}

Arthritis can be induced in rats by administration of Freund's complete adjuvant, without intentional immunization with an exogenous organ-specific autoantigen. Attempts to induce pure adjuvant arthritis in mice or other species have mostly been unsuccessful (7-9). The resistance of mice to adjuvant arthritis was confirmed in our study, in which $<5 \%$ of the wild-type DBA/1 mice developed signs of arthritis. In contrast, IFN $\gamma \mathrm{R}-\mathrm{KO} \mathrm{DBA} / 1$ mice were found to be quite susceptible to arthritis induction with CFA. Induction of arthritis in mice following a single injection of CFA was also observed in BALB/c mice lacking the IFN $\gamma$ receptor, suggesting that CFA-induced arthritis is not MHC class II restricted. Apparently, nonfunctionality of the IFN $\gamma$ system creates favorable conditions for CFA to induce arthritis.

Clinical symptoms in IFN $\gamma \mathrm{R}-\mathrm{KO} \mathrm{DBA} / 1$ mice were transient, with a peak around day 17-18 postinjection of CFA. On pathologic examination, tissue changes in affected joints were indistinguishable from those in classic CIA: infiltration of the synovium with mononuclear and polymorphonuclear cells, together with hyperplasia of tissue, pannus formation, and bone destruction by multinucleated osteoclasts. Hyperplasia and bone destruction by osteoclasts occurred in both the early (day 26) and the late phases of the disease. In contrast, infiltration of the synovium with immune cells was present in the early phase and diminished subsequently. This may explain the waning of clinical symptoms at later time points.

In rats with adjuvant arthritis, not only are the joints affected, but other organs also exhibit inflammatory infiltration and granuloma formation $(6,32)$. In CFA-treated IFN $\gamma \mathrm{R}-\mathrm{KO}$ mice, in contrast, the histologic appearance of the thyroid, kidneys, pancreas, intestine, lungs, liver, heart, and lymph nodes remained normal. Furthermore, anti-DNA antibodies were undetectable in the serum, a finding that corresponds to the tissue specificity of disease. Only the spleen showed enlargement and structural disruption. The red pulp was extensively expanded and contained a large proportion of myeloid cells. Thus, arthritis induced in IFN $\gamma \mathrm{R}-\mathrm{KO}$ mice by a single injection of CFA is qualitatively iden- 
tical to CIA, differing only by its shorter duration and by a generally lower incidence and severity.

Similar to findings in CIA, we demonstrated in this study that the symptoms of adjuvant arthritis coincide with extramedullary myelopoiesis and expansion of $\mathrm{CD} 11 \mathrm{~b}+$ cells in the spleen. The expansion was observed only in mice deficient in the IFN $\gamma$ receptor, indicating that endogenous IFN $\gamma$ somehow counteracts extramedullary myelopoiesis.

Effects of IFN $\gamma$ on hematopoietic progenitor cells and myelopoiesis have been shown in studies using different stimuli of hemopoietic cytokines (for review, see ref. 36). Of special relevance is a study demonstrating a dramatic effect of the IFN $\gamma$ knockout mutation on hemopoietic remodeling during infection with Mycobacterium tuberculosis bacillus Calmette-Guérin, in which the normal splenic architecture in the IFN $\gamma$-KO mice was found to be effaced by expanding myeloid cells (37). Our observations indicate that a similar process takes place in IFN $\gamma \mathrm{R}-\mathrm{KO}$ mice that undergo immunization protocols in which killed mycobacteria are a component of CFA. Macrophages of IFN $\gamma$-deficient mice may be defective in their ability to destroy the mycobacterial cell bodies. This may result in a long-term activated status of the macrophage, and hence also in persistent stimulation of cytokines such as TNF $\alpha$.

In our model of CFA-induced arthritis, $\mathrm{TNF} \alpha$ was detectable in the serum of CFA-sensitized IFN $\gamma \mathrm{R}-\mathrm{KO}$ mice, whereas it was undetectable in wildtype counterparts or in naive mice. Moreover, a portion of the $\mathrm{CD} 11 \mathrm{~b}+$ cells in splenocyte cultures derived from CFA-sensitized IFN $\gamma \mathrm{R}-\mathrm{KO}$ mice, but not in those derived from naive mice, did contain $\mathrm{TNF} \alpha$. Stimulation with mycobacteria further increased the amount of $\mathrm{TNF} \alpha$ produced per cell. Clearly, in our model the expanding $\mathrm{CD} 11 \mathrm{~b}+$ cell population plays a role as a source of TNF $\alpha$, although other cell sources cannot be excluded.

Our results, in particular the fact that a large proportion of the $\mathrm{CD} 11 \mathrm{~b}+$ cells consisted of osteoclast precursors, provide evidence of a possible link between the myelopoietic events and joint involvement, as has been described in experimental arthritis in $\mathrm{TNF} \alpha$ transgenic mice $(23,24)$. Moreover, osteoclasts were inducible in cultured splenocytes, and in much larger numbers in cultures from CFA-sensitized mice than in those from naive mice. In the blood of sensitized mice, the number of osteoclast precursors was likewise increased, as was evident both from the increased proportion of $\mathrm{CD} 11 \mathrm{~b}+, \mathrm{CD} 115+$ cells, known to correspond to osteoclast precursors $(24,34)$, and from osteoclast induc- tion in whole blood leukocytes. Interestingly, the proportion of $\mathrm{CD} 11 \mathrm{~b}+, \mathrm{CD} 115+$ cells was higher in arthritic CFA-sensitized IFN $\gamma \mathrm{R}-\mathrm{KO}$ mice than in nonarthritic CFA-sensitized IFN $\gamma \mathrm{R}-\mathrm{KO}$ mice.

The osteoclasts were fully functional, as evidenced by the pit formation on quartz substrates coated with calcium phosphate film. Apparently, nonfunctionality of IFN $\gamma$ creates favorable conditions for CFA to stimulate systemic generation of excess osteoclast precursors. Mature osteoclasts were not observed in freshly isolated spleen and blood cells of CFA-injected mice, indicating that the osteoclast precursor cells most likely mature into the joints.

Why circulating precursors are attracted to the synovium remains enigmatic, a key question being whether only preinflamed joints can attract or bind the precursor, or whether precursors have inherent affinity for normal joint components. In the latter case, the mere influx of excess osteoclast precursors into the joints might by itself augment the local inflammatory cytokine load from a physiologic to a pathologic level. In the present study we detected higher levels of RANKL mRNA and lower levels of OPG mRNA were in the synovia of CFA-sensitized IFN $\gamma \mathrm{R}-\mathrm{KO}$ mice than in those of naive mice. TNF $\alpha$ mRNA was also found in the synovia of CFA-sensitized IFN $\gamma \mathrm{R}-\mathrm{KO}$ mice, but the levels were comparable with those in naive mice. However, in accordance with the findings of Fuller et al (38), we were able to confirm that TNF $\alpha$ and RANKL act synergistically during osteoclastogenesis, and this synergy was much more pronounced in CFA-sensitized IFN $\gamma \mathrm{R}-\mathrm{KO}$ mice. The presence of both RANKL and $\mathrm{TNF} \alpha$, and the reduced expression of OPG, in the synovia of CFA-sensitized IFN $\gamma \mathrm{R}-\mathrm{KO}$ mice indicate that the conditions for local maturation of precursors to active osteoclasts were fulfilled in our model.

The important role of TNF $\alpha$ in our model is demonstrated by the fact that treatment of the mice with the TNF $\alpha$ antagonist etanercept blocked arthritis development. Even when treatment was stopped on day 28, no clinical symptoms of arthritis were observed during the entire 50-day observation period (data not shown). Based on this protective effect of etanercept against the development of arthritis, we conclude that endogenous $\mathrm{TNF} \alpha$ plays a key role in one or more of the events leading to joint inflammation and bone erosion. Etanercept treatment not only blocked joint involvement, but also prevented splenomegaly. Moreover, the number of multinucleated osteoclasts inducible in splenocyte cultures derived from etanercept-treated CFA-sensitized IFN $\gamma \mathrm{R}-\mathrm{KO}$ mice was reduced to a level below that in 
cultures from control CFA-sensitized IFN $\gamma \mathrm{R}-\mathrm{KO}$ mice. Similarly, the total blood leukocyte population in the etanercept-treated mice contained fewer osteoclast precursors than that in non-etanercept-treated mice. From these findings we conclude that, in our model, $\mathrm{TNF} \alpha$ also has a role in promoting myelopoiesis of the $\mathrm{CD} 11 \mathrm{~b}+$ cell population.

Another point of interest is the observation that treatment with CD4-depleting antibodies prevented CFA-induced arthritis and, in parallel, inhibited the expansion of CD11b + splenocytes as well as osteoclastogenesis. These results indicate an important role of $\mathrm{T}$ cells in driving myelopoiesis. Interestingly, in CIA, antiCD4 antibodies have been described to significantly inhibit the induction of arthritis only when treatment was initiated around the time of immunization with CII in CFA $(39,40)$. Thus, also in CIA, CD4 + T cells may be important in promoting myelopoiesis and osteoclast formation. In fact, from our results it becomes clear that extramedullary myelopoiesis and osteoclastogenesis may be important determinants of arthritis development.

Expansion of $\mathrm{CD} 11 \mathrm{~b}+$ splenocytes and osteoclast precursor cells in blood was significantly more pronounced in mice that developed arthritis than in animals that remained free of symptoms. Therefore, it is tempting to speculate that the expansion of CD11b + cells in spleen and blood may lead to arthritis as soon as its magnitude exceeds a critical value. In this scenario, administration of compounds that keep the expansion below the threshold (in this study, etanercept and antiCD4) would inhibit the development of arthritis.

In summary, our findings reveal previously undescribed roles of CFA in the pathogenesis of CIA. Aside from stimulating the specific autoimmune response, CFA elicits an antigen-independent pathway involving osteoclastogenesis. This innate pathway is cytokine controlled: dysregulation of a single cytokine creates favorable conditions for CFA to stimulate osteoclastogenesis and arthritis. Determining the frequency of peripheral osteoclasts may be important in clarifying the mechanism of action of cytokines in the pathogenesis of CIA and may explain discrepancies in results obtained in different animal models of arthritis.

\section{ACKNOWLEDGMENTS}

We thank A. Billiau, G. Opdenakker, and R. J. Lories for critical reading of the manuscript.

\section{AUTHOR CONTRIBUTIONS}

Ms Geboes had full access to all of the data in the study and takes responsibility for the integrity of the data and the accuracy of the data analysis.
Study design. Geboes, Matthys.

Acquisition of data. Geboes, De Klerck, Van Balen, Kelchtermans, Mitera, Boon, De Wolf-Peeters.

Analysis and interpretation of data. Geboes, De Klerck, De WolfPeeters, Matthys.

Manuscript preparation. Geboes, Matthys.

Statistical analysis. Geboes.

Provision of anti-CD4 antibodies. Boon.

\section{REFERENCES}

1. Courtenay JS, Dallman MJ, Dayan AD, Martin A, Mosedale B. Immunisation against heterologous type II collagen induces arthritis in mice. Nature 1980;283:666-8.

2. Wooley PH, Chapedelaine JM. Immunogenetics of collageninduced arthritis. Crit Rev Immunol 1987;8:1-22.

3. Brand DD, Kang AH, Rosloniec EF. Immunopathogenesis of collagen arthritis. Springer Semin Immunopathol 2003;25:3-18.

4. Billiau A, Matthys P. Modes of action of Freund's adjuvants in experimental models of autoimmune diseases. J Leukoc Biol 2001;70:849-60.

5. Mauri C, Feldmann M, Williams RO. Down-regulation of Th1mediated pathology in experimental arthritis by stimulation of the Th2 arm of the immune response. Arthritis Rheum 2003;48: 839-45.

6. Holmdahl R, Lorentzen JC, Lu S, Olofsson P, Wester L, Holmberg $\mathrm{J}$, et al. Arthritis induced in rats with nonimmunogenic adjuvants as models for rheumatoid arthritis. Immunol Rev 2001; 184:184-202.

7. Knight B, Katz DR, Isenberg DA, Ibrahim MA, le Page S, Hutchings $\mathrm{P}$, et al. Induction of adjuvant arthritis in mice. Clin Exp Immunol 1992;90:459-65.

8. Ratkay LG, Zhang L, Tonzetich J, Waterfield JD. Complete Freund's adjuvant induces an earlier and more severe arthritis in MRL-lpr mice. J Immunol 1993;151:5081-7.

9. Chillingworth NL, Donaldson LF. Characterisation of a Freund's complete adjuvant-induced model of chronic arthritis in mice. J Neurosci Methods 2003;128:45-52.

10. Yoshino S, Murata Y, Ohsawa M. Successful induction of adjuvant arthritis in mice by treatment with a monoclonal antibody against IL-4. J Immunol 1998;161:6904-8.

11. Manoury-Schwartz B, Chiocchia G, Bessis N, Abehsira-Amar O, Batteux F, Muller S, et al. High susceptibility to collagen-induced arthritis in mice lacking IFN- $\gamma$ receptors. J Immunol 1997;158: 5501-6.

12. Vermeire K, Heremans H, Vandeputte M, Huang S, Billiau A, Matthys P. Accelerated collagen-induced arthritis in IFN- $\gamma$ receptor-deficient mice. J Immunol 1997;158:5507-13.

13. Kelchtermans H, de Klerck B, Mitera T, van Balen M, Bullens D, Billiau A, et al. Defective $\mathrm{CD} 4{ }^{+} \mathrm{CD} 25^{+}$regulatory T cell functioning in collagen-induced arthritis: an important factor in pathogenesis, counter-regulated by endogenous IFN- $\gamma$. Arthritis Res Ther 2005; 7:R402-15.

14. Chu CQ, Song Z, Mayton L, Wu B, Wooley PH. IFN $\gamma$ deficient C57BL/6 (H-2b) mice develop collagen induced arthritis with predominant usage of $\mathrm{T}$ cell receptor $\mathrm{V} \beta 6$ and $\mathrm{V} \beta 8$ in arthritic joints. Ann Rheum Dis 2003;62:983-90.

15. Guedez YB, Whittington KB, Clayton JL, Joosten LA, van de Loo FA, van den Berg WB, et al. Genetic ablation of interferon- $\gamma$ up-regulates interleukin- $1 \beta$ expression and enables the elicitation of collagen-induced arthritis in a nonsusceptible mouse strain. Arthritis Rheum 2001;44:2413-24.

16. Matthys P, Vermeire K, Mitera T, Heremans H, Huang S, Schols $\mathrm{D}$, et al. Enhanced autoimmune arthritis in IFN- $\gamma$ receptordeficient mice is conditioned by mycobacteria in Freund's adjuvant 
and by increased expansion of Mac- $1^{+}$myeloid cells. J Immunol 1999;163:3503-10.

17. Campbell IK, Hamilton JA, Wicks IP. Collagen-induced arthritis in $\mathrm{C} 57 \mathrm{BL} / 6(\mathrm{H}-2 \mathrm{~b})$ mice: new insights into an important disease model of rheumatoid arthritis. Eur J Immunol 2000;30:1568-75.

18. De Klerck B, Carpentier I, Lories RJ, Habraken Y, Piette J, Carmeliet G, et al. Enhanced osteoclast development in collageninduced arthritis in interferon- $\gamma$ receptor knock-out mice as related to increased splenic CD11b+ myelopoiesis. Arthritis Res Ther 2004;6:R220-31.

19. Walsh MC, Kim N, Kadono Y, Rho J, Lee SY, Lorenzo J, et al. Osteoimmunology: interplay between the immune system and bone metabolism. Annu Rev Immunol 2006;24:33-63.

20. Wada T, Nakashima T, Hiroshi N, Penninger JM. RANKL-RANK signaling in osteoclastogenesis and bone disease. Trends Mol Med 2006;12:17-25.

21. Yasuda H, Shima N, Nakagawa N, Yamaguchi K, Kinosaki M, Mochizuki S, et al. Osteoclast differentiation factor is a ligand for osteoprotegerin/osteoclastogenesis-inhibitory factor and is identical to TRANCE/RANKL. Proc Natl Acad Sci U S A 1998;95: 3597-602.

22. Redlich K, Hayer S, Maier A, Dunstan CR, Tohidast-Akrad M, Lang $\mathrm{S}$, et al. Tumor necrosis factor $\alpha$-mediated joint destruction is inhibited by targeting osteoclasts with osteoprotegerin. Arthritis Rheum 2002:46:785-92.

23. Redlich K, Hayer S, Ricci R, David JP, Tohidast-Akrad M, Kollias $\mathrm{G}$, et al. Osteoclasts are essential for TNF- $\alpha$-mediated joint destruction. J Clin Invest 2002;110:1419-27.

24. Li P, Schwarz EM, O'Keefe RJ, Ma L, Looney RJ, Ritchlin CT, et al. Systemic tumor necrosis factor $\alpha$ mediates an increase in peripheral $\mathrm{CD} 11 \mathrm{~b}^{\text {high }}$ osteoclast precursors in tumor necrosis factor $\alpha$-transgenic mice. Arthritis Rheum 2004;50:265-76.

25. Yao Z, Li P, Zhang Q, Schwarz EM, Keng P, Arbini A, et al. Tumor necrosis factor- $\alpha$ increases circulating osteoclast precursor numbers by promoting their proliferation and differentiation in the bone marrow through up-regulation of c-Fms expression. J Biol Chem 2006;281:11846-55.

26. Huang S, Hendriks W, Althage A, Hemmi S, Bluethmann H, Kamijo R, et al. Immune response in mice that lack the interferon- $\gamma$ receptor. Science 1993;259:1742-5.

27. Mosmann T. Rapid colorimetric assay for cellular growth and survival: application to proliferation and cytotoxicity assays. J Immunol Methods 1983;65:55-63.

28. Livak KJ, Schmittgen TD. Analysis of relative gene expression data using real-time quantitative PCR and the $2^{\Delta \Delta C}$ Method. Methods 2001;25:402-8.

29. Nissler K, Pohlers D, Huckel M, Simon J, Brauer R, Kinne RW. Anti-CD4 monoclonal antibody treatment in acute and early chronic antigen induced arthritis: influence on macrophage activation. Ann Rheum Dis 2004;63:1470-7.

30. Matthys P, Lories RJ, de Klerck B, Heremans H, Luyten FP, Billiau A. Dependence on interferon- $\gamma$ for the spontaneous occurrence of arthritis in DBA/1 mice. Arthritis Rheum 2003;48:2983-8.

31. Tagawa Y, Sekikawa K, Iwakura Y. Suppression of concanavalin A-induced hepatitis in IFN- $\gamma^{-/-}$mice, but not in TNF- $\alpha^{-1-}$ mice: role for IFN- $\gamma$ in activating apoptosis of hepatocytes. J Immunol 1997;159:1418-28.

32. Waksman BH. Immune regulation in adjuvant disease and other arthritis models: relevance to pathogenesis of chronic arthritis. Scand J Immunol 2002;56:12-34.

33. Schett G, Redlich K, Hayer S, Zwerina J, Bolon B, Dunstan C, et al. Osteoprotegerin protects against generalized bone loss in tumor necrosis factor-transgenic mice. Arthritis Rheum 2003;48: 2042-51.

34. Arai F, Miyamoto T, Ohneda O, Inada T, Sudo T, Brasel K, et al. Commitment and differentiation of osteoclast precursor cells by the sequential expression of c-Fms and receptor activator of nuclear factor $\kappa \mathrm{B}$ (RANK) receptors. J Exp Med 1999;190: 1741-54.

35. Lacey DL, Timms E, Tan HL, Kelley MJ, Dunstan CR, Burgess T, et al. Osteoprotegerin ligand is a cytokine that regulates osteoclast differentiation and activation. Cell 1998;93:165-76.

36. Billiau A. Interferon- $\gamma$ : biology and role in pathogenesis. Adv Immunol 1996;62:61-130.

37. Murray PJ, Young RA, Daley GQ. Hematopoietic remodeling in interferon- $\gamma$-deficient mice infected with mycobacteria. Blood 1998;91:2914-24.

38. Fuller K, Murphy C, Kirstein B, Fox SW, Chambers TJ. TNF $\alpha$ potently activates osteoclasts, through a direct action independent of and strongly synergistic with RANKL. Endocrinology 2002;143: $1108-18$.

39. Williams RO, Whyte A. Anti-CD4 monoclonal antibodies suppress murine collagen-induced arthritis only at the time of primary immunisation. Cell Immunol 1996;170:291-5.

40. Williams RO, Feldmann M, Maini RN. Cartilage destruction and bone erosion in arthritis: the role of tumour necrosis factor $\alpha$. Ann Rheum Dis 2000;59 Suppl 1:i75-80. 